\title{
Erratum to: Sequential treatment for a patient with hemifacial microsomia: 10 year-long term follow up
}

Jeong-Seok Seo, Young-Chea Roh, Jae-Min Song, Won-Wook Song, Hwa-Sik Seong, Si-Yeob Kim, Dae-Seok Hwang and Uk-Kyu Kim*

\section{Erratum}

After the "Competing interests" section in the original version of this article [1], an "Acknowledgements" section should be inserted and read as: "This research was supported by Basic Science Research Program through the National Research Foundation of Korea (NRF) funded by the Ministry of Education (2012R1A1A2003550)'.

Received: 20 May 2015 Accepted: 20 May 2015

Published online: 17 June 2015

\section{Reference}

1. Seo JS, Roh YC, Song JM, Song WW, Seong HS, Kim SY, Hwang DS, Kim UK

(2015) Sequential treatment for a patient with hemifacial microsomia:

10 year-long term follow up. Surger, Maxillofacial Plastic and Reconstructive.

Submit your manuscript to a SpringerOpen ${ }^{\circ}$ journal and benefit from:

- Convenient online submission

- Rigorous peer review

- Immediate publication on acceptance

- Open access: articles freely available online

- High visibility within the field

- Retaining the copyright to your article

Submit your next manuscript at $\boldsymbol{\nabla}$ springeropen.com 